\title{
Eutrophication: Present reality and future challenges for South Africa
}

\author{
CE van Ginkel* \\ Cripsis Environment, $59020^{\text {th }}$ Avenue, Rietfontein 0084, Pretoria, South Africa
}

\begin{abstract}
During the past 40 years, eutrophication has become an increasing threat to the usability of South African freshwater resources. Despite legislation moderating the discharge of phosphorus from some wastewater treatment works since the 1980s, eutrophication of freshwater resources is now widespread. Two important consequences are blooms of cyanobacteria, carrying the threat of cyanotoxin contamination, and excessive growth of macrophytes, which clog water-supply structures and reduce the recreational value of aquatic resources. Eutrophication-management options include reduction of phosphorus in detergents, biomanipulation of the food web, accurate prediction of cyanobacterial growth cycles, and mechanical disturbance of the epilimnion. The implementation of adaptive management to deal with eutrophication would ensure the testing and application of the most appropriate methodology to each eutrophic water body. Continued monitoring and reporting of trophic status are essential to establish whether interventions are having any effect.
\end{abstract}

Keywords: biomanipulation, cyanobacteria, eutrophication, forward prediction, management, low-p detergents, phosphorus, zero-phosphate

\section{Introduction}

Eutrophication is the process of nutrient enrichment and the associated excessive plant growth in water bodies. It is part of the natural ageing process of lakes and is accelerated by human impacts. High nutrient concentrations are the result of cultural and natural influxes of nutrients (Fig. 1).

Cultural eutrophication is related to anthropogenic activities - human, social and economic activities. In theory, this form of eutrophication is controllable, because people can take measures to minimise the impact of their activities. Wellknown impacts of cultural eutrophication include:

- Accelerated population growth and associated settlement patterns

- Watershed or catchment area alterations, such as dams that are built for water storage to supply increasing population needs

- Increased wastewater treatment works discharges

- Increased fertiliser applications to increase food production

- Intensive farming practices that cause increased nutrientpolluted return flows

- Poor agricultural practices, for example when farmers plough and cultivate the riparian zones of water resources

Natural eutrophication is caused by the influx of nutrients from natural sources, including the rocks, soil and other natural features within a catchment area. This type of eutrophication is not reversible or controllable, and will therefore continue slowly and inevitably.

This paper was originally presented at the Water Research Commission 40-Year Celebration Conference, Kempton Park,

31 August - 1 September 2011.

* To whom all correspondence should be addressed.

푤 +27 12 755-9855; fax: +27 86 547-5621; e-mail: carin.vanginkel@gmail.com

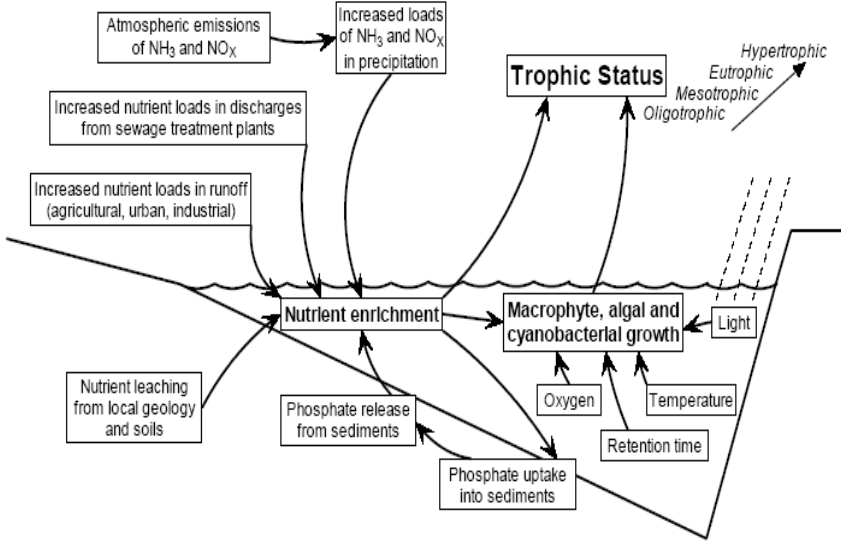

Figure 1

The nutrient cycle within a water system, indicating the causes and consequences of eutrophication (copied from DWA, 2002)

The factors driving eutrophication are high nutrient concentration and stagnation for prolonged periods, with suitable temperature, oxygen concentration and proper light regime. These conditions encourage increased primary growth in the form of algae and macrophytes, culminating in severe blooms and eutrophication or, in extreme cases, a hypertrophic state.

In this paper the current situation regarding eutrophication in South Africa will be assessed and the future challenges facing the country will be identified against a historical background of research and management initiatives. The current reality of the eutrophication situation faced by the country will be outlined, and an account will be given of a number of the more recent initiatives to manage eutrophication, as well as a description of an adaptive management process through which it is proposed that the eutrophication problems be addressed in future. 


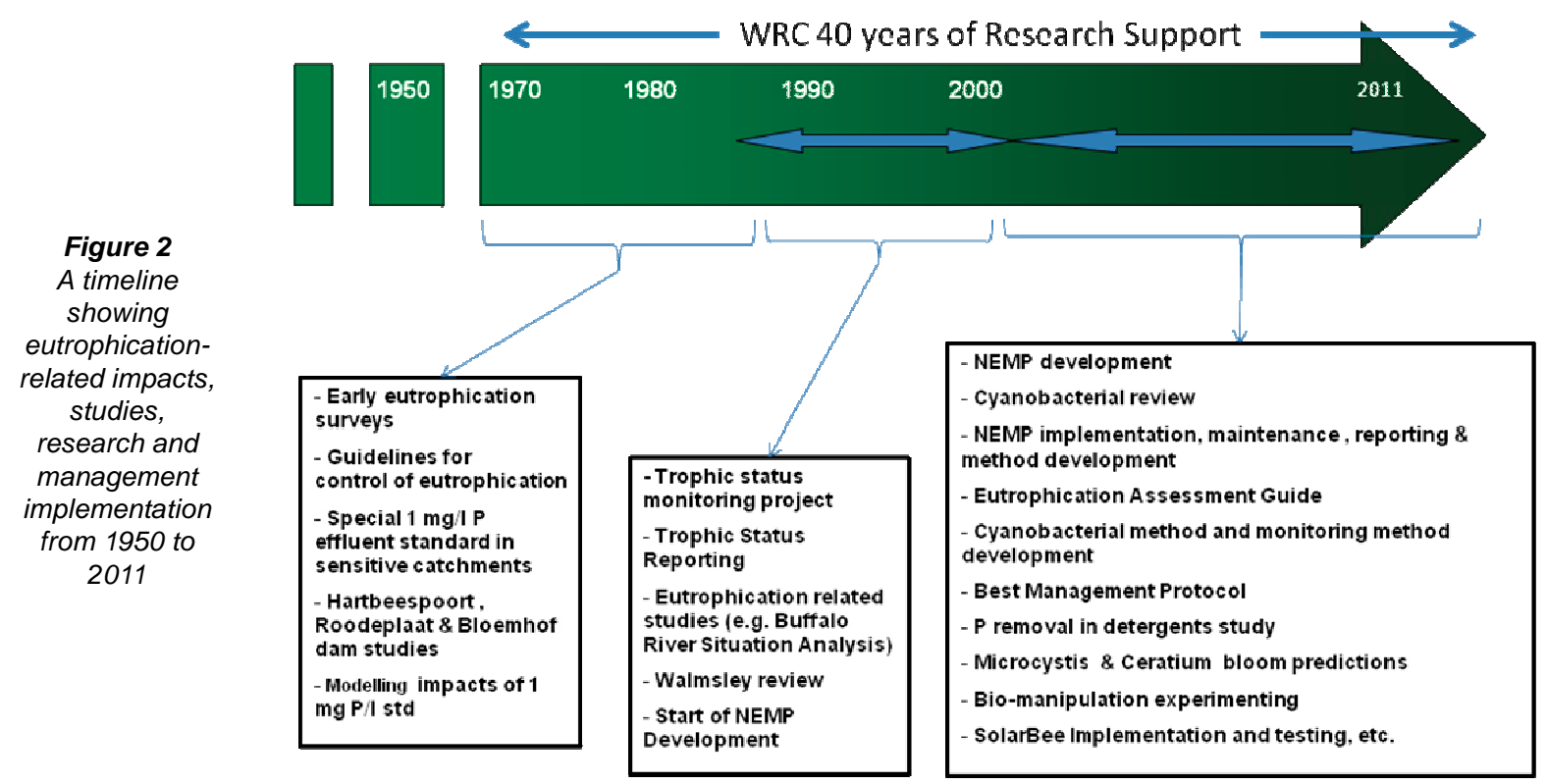

\section{History of eutrophication research and management in South Africa}

The history of eutrophication research and management in South Africa is schematically illustrated in Fig. 2. Numerous studies drew attention to the eutrophication problem in the late 1970s and early 1980s and many eutrophication-management options were suggested (e.g. Toerien, 1977; Walmsley and Butty, 1980; Zohary et al., 1988). An effluent standard of $1 \mathrm{mg} / \ell$ orthophosphate for wastewater discharges from point sources was therefore promulgated by DWAF on 1 August 1980 (Water, 1988). Note that the $1 \mathrm{mg} P / \ell$ standard is an effluent discharge standard, not an in-stream or inlake standard. The ameliorating effects of natural in-stream processes are relied upon to act on the discharged effluent and reduce nutrient concentrations to acceptable levels within a river system. Unfortunately, the capacity of in-stream processes to achieve the desired nutrient reduction is often exceeded (Hohls, 1998).

During 1985 the Department of Water Affairs initiated the first eutrophication-focused monitoring programme, which covered the 7 sensitive catchments mentioned in the Government Gazette Notice No. 1567. Unfortunately, the Department of Water Affairs acceded to requests from many of the affected authorities by exempting them for 5 years from compliance with the $1 \mathrm{mg} \mathrm{P} / \ell$ standard (Taylor et al., 1984; Van der Merwe, 1989; Van Ginkel et al., 2001).

During the period 1985 to 1988, the Department of Water Affairs and the CSIR completed an investigation, using the Reservoir Eutrophication Model (REM), to predict the impact of the P-standard on water quality in the sensitive catchments (Grobler and Silberbauer, 1984; Rossouw, 1990). On the basis of these findings the target water quality aimed to control eutrophication was set 'to maintain mean chlorophyll concentrations in the receiving water bodies at such levels that severe nuisance conditions would not occur for more than $20 \%$ of the time. This translated into a phosphorus management objective (PMO) or endpoint of maintaining mean total phosphorus concentrations in reservoirs at $130 \mu \mathrm{g} / \ell \mathrm{P}$ or lower (DWA, 1988; ANON, 1988a; ANON, 1988b).

During the 1990s South African eutrophication-related work focused only on specific impacted areas, for example the Buffalo River Situation Analysis (Van Ginkel et al., 1996). The aim of the Buffalo River study was to understand all the pathways and impacts related to eutrophication within the specific catchment areas. During the late 1990s and early 2000s, the Department of Water Affairs and the WRC assessed the shortcomings in eutrophication research and management with a specific focus on the WRC's contribution and the impact of its research (Walmsley, 2000; Harding, 2006; Frost \& Sullivan, 2010). The result was a renewed focus on eutrophication-related problems and management options after 2000 (Quayle et al., 2010; Van Ginkel et al., 2009).

\section{Eutrophication reality in South Africa}

South Africa's most limiting natural resource is freshwater (Van Ginkel et al., 2001). Thus, the provision of safe and sufficient drinking water in South Africa relies on the availability of freshwater resources.

From 1985 onward, the Department of Water Affairs focused its monitoring on areas affected by eutrophication through the Trophic Status Project. After the implementation of the National Eutrophication Monitoring Programme (NEMP) in 2002, the Department also began regularly releasing data maps indicating the extent of eutrophication thereby improving the knowledge about eutrophication in South Africa for an increasing number of sites. The classification system for the sampling sites used by the Department of Water Affairs is shown in Table 1.

From Fig. 3 it is clear that South Africa is facing widespread eutrophication-related problems, most of them associated with the larger metropolitan areas and the dams on which these areas rely for their water supplies.

The main reasons for viewing eutrophication of freshwater resources as a serious problem, which threatens our ability to supply sufficient and safe drinking water to an increasing population, are the following accompanying factors:

- Production of cyanotoxins and their potential impact on the health of end users

- Financial implications of dealing with noxious macrophyte control 

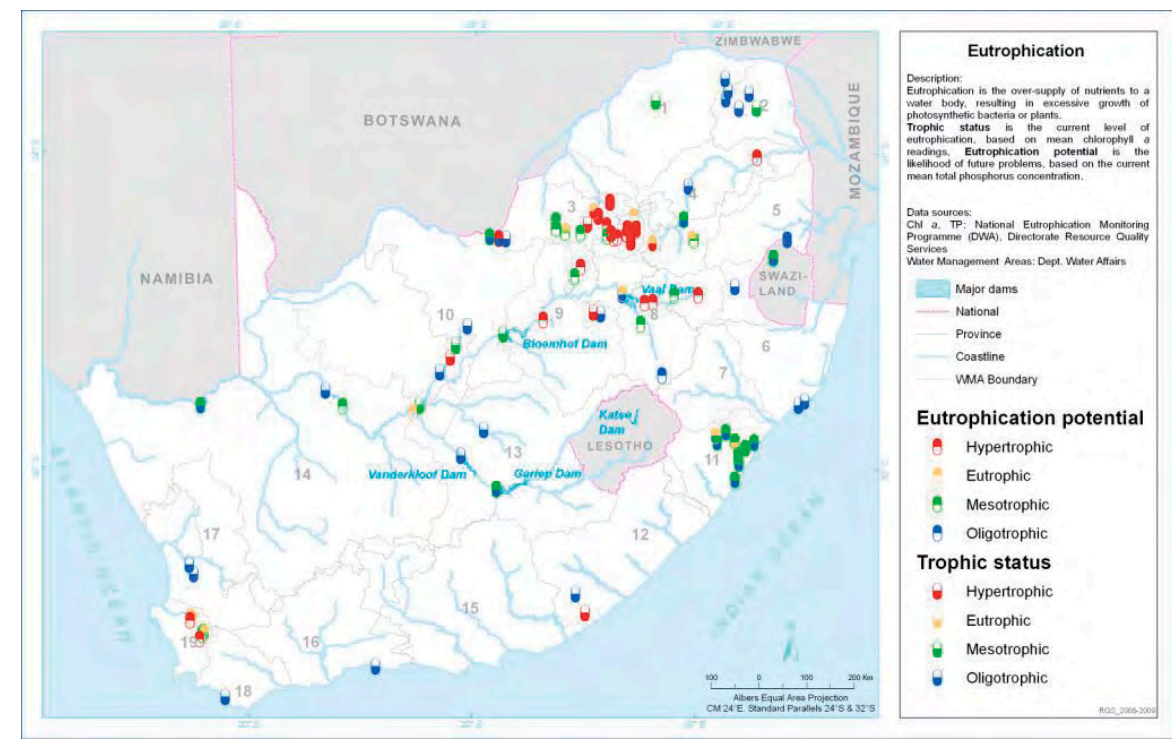

Figure 3

Map showing

overall

eutrophication

impacts in the

19 catchment

management areas

in South Africa

(provided by RQS,

DWA, 2009)

Table 1

The classification system used by the Department Water Affairs to classify the National Eutrophication Monitoring Programme sites regarding their trophic status and eutrophication potential statistics (DWAF, 2002)

\begin{tabular}{|c|c|c|c|c|c|}
\hline \multirow{3}{*}{\begin{tabular}{|l} 
Statistic \\
$\begin{array}{l}\text { Mean annual } \\
\text { chlorophyll } a\end{array}$ \\
\end{tabular}} & \multirow{3}{*}{\begin{tabular}{|l} 
Unit \\
$\mu \mathrm{g} / \ell$
\end{tabular}} & \multicolumn{4}{|c|}{ Current trophic status: } \\
\hline & & $0<\mathrm{x} \leq 10$ & $10<x \leq 20$ & $20<x \leq 30$ & $>30$ \\
\hline & & Oligotrophic (low) & Mesotrophic (moderate) & Eutrophic (significant) & Hypertrophic (serious) \\
\hline \multirow{3}{*}{$\begin{array}{l}\% \text { of time } \\
\text { chlorophyll } \\
a>30 \mu \mathrm{g} / \ell\end{array}$} & \multirow{3}{*}{$\%$} & \multicolumn{4}{|c|}{ Current nuisance value of algal bloom productivity: } \\
\hline & & 0 & $0<\mathrm{x} \leq 8$ & $8<x \leq 50$ & $>50$ \\
\hline & & negligible & moderate & significant & serious \\
\hline \multirow{3}{*}{$\begin{array}{l}\text { Mean annual total } \\
\text { phosphorus }\end{array}$} & \multirow{3}{*}{$\mathrm{mg} / \ell$} & \multicolumn{4}{|c|}{ Potential for algal and plant productivity: } \\
\hline & & $\mathrm{x} \leq 0.015$ & $0.015<\mathrm{x} \leq 0.047$ & $0.047<\mathrm{x} \leq 0.130$ & $>0.130$ \\
\hline & & negligible & moderate & significant & serious \\
\hline
\end{tabular}

\section{Cyanobacterial blooms}

Cyanobacterial blooms and their effects are symptoms of increasing eutrophication. They are widespread, frequent and typically seasonal. Many cyanobacterial genera produce one or more of a range of cyanotoxins (WHO, 1999) and many are associated with taste and odour problems encountered by water treatment works (Wnorowski 1992; Swanepoel et al., 2008). The ingestion of water containing high concentrations of cyanobacterial toxin (in drinking or in recreational waters) presents a risk to human and animal health (Pouria et al., 1998; WHO, 1999; Botes et al., 2004). The increasing frequency of cyanobacterial blooms in South African impoundments and rivers is a cause for concern. Since 1990 the research focus, internationally and nationally, has shifted to expanding our knowledge of the driving forces behind cyanobacterial blooms and cyanotoxin production. Toxic cyanobacterial blooms are a threat to the supply of safe drinking water in large parts of South Africa (Van Ginkel, 2004), especially in areas where water purification is minimal or not fully functional (Van Ginkel and Conradie, 2001).

Microcystis spp. are the dominant bloom-forming cyanobacterial species present in South Africa (Wnorowski, 1992; Harding and Paxton, 2001; Downing and Van Ginkel, 2003; Van Ginkel, 2004). Additionally Oscillatoria spp. (Harding and Paxton, 2001, Van Ginkel and Conradie, 2001) and Cylindrospermopsis (Van Ginkel and Conradie, 2001) occur in bloom-forming condition.

Production of cyanobacterial toxins in 5 South African hypertrophic systems is several orders of magnitude higher than figures reported for northern hemisphere countries (Fig. 4 and Fig. 5). The 5 most hypertrophic systems in South Africa have cyanotoxin concentrations in excess of $1 \mu \mathrm{g} / \ell$ for more than $80 \%$ of the time (Fig. 4). South African maximum total microcystin concentrations are also much higher than those reported in Finland and North America.

The severity of cyanobacterial blooms in South Africa is evident from the number of livestock and wild animal deaths recorded since 1950 (Harding and Paxton, 2001). Eutrophication-related contamination of water also occurs in the Kruger National Park and several mammal deaths were reported during 2005 and 2007 (Oberholster, 2009). Clearly, management techniques aimed at preventing widespread cyanotoxin poisoning need to be applied in South Africa.

\section{Excessive macrophyte growth}

The presence of high concentrations of nutrients supports the rapid growth of macrophytes. Excessive macrophyte biomass blocks waterways, impedes access to dams and rivers, clogs drainage systems and contributes to flooding and the destruction of canals.

Water hyacinth (Eichhornia crassipes) control alone costs South Africa in the order of R12 million per annum. 


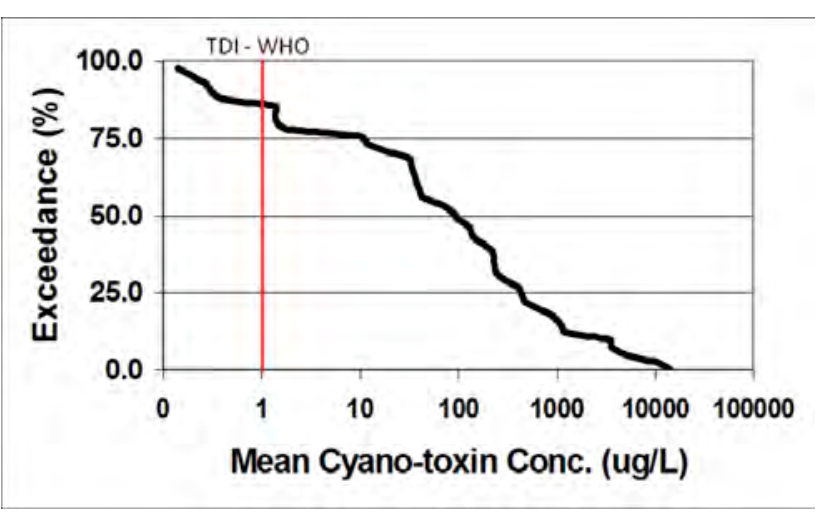

Figure 4

The percentage of time that cyanotoxin concentrations (total microcystin concentrations) in 5 hypertrophic impoundments of South Africa (2003-2004) exceed the TDI (total daily intake concentrations) as specified by the World Health Organization (WHO, 1999) (Van Ginkel et al., 2006)

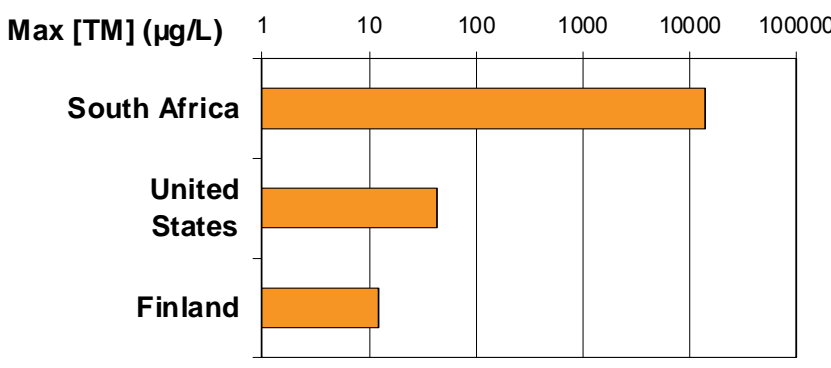

Figure 5

A comparison of the maximum total microcystin concentration reported in studies from Finland, USA and South Africa (Johnston and Jacoby, 2003; Lindholm et al., 2003; Van Ginkel et al., 2006)

The widespread economic damage is matched by the ecological effects which result in the displacement of indigenous flora and fauna through habitat alteration (Byrne et al., 2010). Many aquatic macrophytes are exotic, problem-causing species, including water hyacinth, red water fern (Azolla spp.), water lettuce (Pistia stratiotes), Kariba weed (Salvinia molesta), Hydrilla (Hydrilla verticillata) and parrot's feather (Myriophyllum aquaticum). Hydrilla is the latest addition to this list of problematic species, although its presence was already recorded in South Africa as early as 1963 (Coetzee et al., 2011b).

Extensive research has been done on the management of these noxious aquatic weeds. Many biological control methods (Cilliers, 1991; Cilliers et al., 2003; Modjadje Vegetation, 2008; Coetzee et al., 2011a) and chemical control methods have been implemented with varying degrees of success. An integrated approach appears to be the most promising solution to combat aquatic weeds, especially water hyacinth (Modjadje Vegetation, 2008; Byrne et al., 2010).

\section{Eutrophication management}

Over the years, it became increasingly apparent that South Africa needs to perform pilot testing of eutrophication-management options to determine their effectiveness and applicability for implementation at other impacted sites. This realisation prompted the initiation of management-focused research

\begin{tabular}{|l|c|c|c|}
\hline \multicolumn{4}{|c|}{$\begin{array}{c}\text { Table 2 } \\
\text { Selected dams showing the time dams will spend in a } \\
\text { non-eutrophic state (55 } \mathbf{\mu g} \text { P/ } \\
\text { detergents and with P-free detergents. The expected } \\
\text { percentage change is also indicated (Quayle, 2010) }\end{array}$} \\
\hline Dam & $\begin{array}{c}\text { With-P } \\
\text { detergent }\end{array}$ & $\begin{array}{c}\text { Low-P } \\
\text { detergent }\end{array}$ & Change \\
\hline Hartbeespoort & $12.3 \%$ & $27.7 \%$ & $15.4 \%$ \\
\hline Shongweni & $65.4 \%$ & $77.8 \%$ & $12.4 \%$ \\
\hline Klipfontein & $17.3 \%$ & $27.5 \%$ & $10.2 \%$ \\
\hline Laing & $4.8 \%$ & $13.4 \%$ & $8.6 \%$ \\
\hline Bloemhof & $20.5 \%$ & $27.9 \%$ & $7.4 \%$ \\
\hline Hazelmere & $84.3 \%$ & $91.6 \%$ & $7.3 \%$ \\
\hline Grootdraai & $41.9 \%$ & $48.1 \%$ & $6.2 \%$ \\
\hline Henley & $74.3 \%$ & $79.2 \%$ & $4.9 \%$ \\
\hline Bronkhorstspruit & $24.6 \%$ & $28.4 \%$ & $3.8 \%$ \\
\hline Lindleyspoort & $60.1 \%$ & $63.6 \%$ & $3.5 \%$ \\
\hline Roodekopjes & $73.4 \%$ & $76.4 \%$ & $3.0 \%$ \\
\hline Vaal & $25.0 \%$ & $28.0 \%$ & $3.0 \%$ \\
\hline Inanda & $95.3 \%$ & $98.0 \%$ & $2.7 \%$ \\
\hline Roodeplaat & $3.3 \%$ & $5.1 \%$ & $1.8 \%$ \\
\hline Midmar & $92.5 \%$ & $94.3 \%$ & $1.8 \%$ \\
\hline Albert Falls & $86.9 \%$ & $88.5 \%$ & $1.6 \%$ \\
\hline Klipvoor & $1.2 \%$ & $2.7 \%$ & $1.5 \%$ \\
\hline Koppies & $14.5 \%$ & $15.8 \%$ & $1.3 \%$ \\
\hline Misverstand & $6.5 \%$ & $7.7 \%$ & $1.2 \%$ \\
\hline Allemanskraal & $12.4 \%$ & $12.8 \%$ & $0.4 \%$ \\
\hline Nagle & $89.3 \%$ & $89.7 \%$ & $0.4 \%$ \\
\hline Witbank & $84.9 \%$ & $85.2 \%$ & $0.3 \%$ \\
\hline Erfenis & $1.5 \%$ & $1.8 \%$ & $0.3 \%$ \\
\hline Welbedacht & $28.2 \%$ & $28.2 \%$ & $0.0 \%$ \\
\hline
\end{tabular}

through the WRC (Pillay and Buckley, 2001; Rossouw et al., 2008). A number of the more recent case studies that have been or are being conducted to investigate plausible options to manage eutrophication are discussed below.

\section{Low-P detergents}

It is acknowledged that the most effective method to combat nutrient enrichment is to minimise the influx of nutrients into freshwater systems. This perspective prompted the reinvestigation of means to control the influx of phosphate into water bodies. The first study in this regard was to investigate the desirability of introducing low phosphorus detergents. The WRC consequently commissioned a project entitled 'Investigation of the positive and negative consequences associated with the introduction of zero-phosphate detergents into South Africa', with the main aims of determining:

- The contribution of detergent phosphates to the phosphate loading at wastewater treatment facilities

- The potential impact of introducing low- to zero-phosphate detergents into South Africa (Quayle et al., 2010).

Impacts of the removal of detergent phosphorus on in-dam phosphate and chlorophyll $a$ levels were modelled based on predicted reductions in inflow loading using the OECD eutrophication model Jones and Lee, 1982) and the Walker Reservoir Models (Thornton and Harding, 2005). Results show a variable decrease in total phosphorus ranging from 3\% - 35\%, largely dependent on the demographics of each catchment. A mean reduction of $12 \%$ across all dams was calculated (Quayle et al., 2010). 
Next, a number of dams were studied to determine the potential effect that the introduction of zero-phosphate detergent can be expected to have on the time dams spend in a non-eutrophic state $(55 \mu \mathrm{g} / \ell$ total phosphorus in-lake median concentration used as a threshold (Harding, 2008)) (Table 2). It is clear that some dams could potentially receive a much lower phosphorus input, especially the most hypertrophic sites. Although this is not the ultimate management option and will not eliminate phosphates from freshwater systems, it is potentially the first important step towards active control of eutrophication in South Africa since the implementation of the $1 \mathrm{mg} \mathrm{P} / \ell$ standard in 1980. Legislation should compel detergent manufacturers to produce low-phosphate or phosphate-free detergents. To promote their use they should be made available at the same cost as detergents containing phosphate. At least one large manufacturer has already undertaken to do this voluntarily (Quayle, 2011).

\section{Biomanipulation}

Biomanipulation techniques target food-chain functioning and involve the use or harvesting of non-desirable organisms to eventually control algal growth or other components of the food chain that may cause eutrophication-related problems. The main aim is to control certain key species at critical points in the food web, e.g. fish species that prey on zooplankton to an extent that may alter the normal functioning of the ecosystem. These methods have been studied extensively in the northern hemisphere, but need to be tested locally in order to evaluate their applicability under South African climatic conditions. The northern hemisphere test sites were in cooler regions with shorter summer seasons than South Africa.

DH Environmental Consulting, funded by the Finnish Government in association with DEA and DWA, developed a management plan for the Hartbeespoort Dam. The Department of Water Affairs continued its support of this initiative by funding a project (Harties, Metsi a Me) on the Hartbeespoort Dam to combat the severe eutrophication impacts in this system. This project is testing an integrated water-management system and is managed by the Regional DWA Office at Hartbeespoort Dam. They are testing methodologies, monitoring quite extensively, harvesting fish and improving upstream wetlands. One of the objectives of the project is to improve the zooplankton concentration. At time of publication the project is ongoing and a final assessment is not available, but preliminary results suggest that the concentration of filter-feeding cladoceran zooplankton increased during the summer period from 2008 to 2010 (Fig. 6).

The efficacy of the eutrophication-management methods used for Hartbeespoort Dam still needs to be confirmed during the final evaluation of the successes and failures of the project in combination with results of the monitoring initiative. For example, evidence is needed to support the hypothesis that the gradual increase of filter-feeding cladoceran zooplankton, specifically during summer, is the result of a greater abundance of the edible algal species preferred by zooplankton present in the system, which in turn came about in response to the manipulation of the food chain by fish harvesting.

\section{Prediction of cyanobacterial blooms}

The regular occurrence of cyanobacterial blooms and the potential health hazard posed by cyanotoxin production necessitate the development of forecasting tools. This will enable

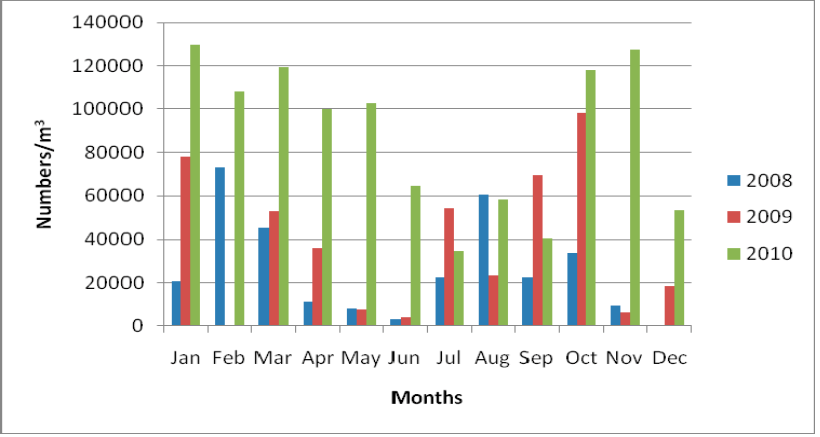

Figure 6

Annual seasonal changes in total numbers of the filter-feeding cladoceran zooplankton in Hartbeespoort Dam from 2008 to 2010 (Van Ginkel, 2011)

effective risk management by potable water-treatment works operators and controllers and provide early warning for recreational users. By implementing a forward prediction model to determine cyanobacterial bloom development, a water-treatment works controller will know when to stop pre-chlorination. The release of cyanotoxins into the treated water through die-off of algal cells during the pre-chlorination process is thus prevented (Swanepoel et al., 2008). Forewarning of abnormal conditions also enables a water-treatment process manager to purchase extra supplies, such as the case where activated carbon is not part of the normal treatment procedures.

The WRC funded a study that investigated the effectiveness of different models for forward prediction of cyanobacterial biomass (Van Ginkel et al., 2009). The hybrid evolutionary algorithm method, used to develop a rule-based agent for the forward prediction of Microcystis biomass in hypertrophic reservoirs of South Africa, proved to be the best. Data from Hartbeespoort Dam, Roodeplaat Dam and Rietvlei Dam for the period 1991 to 2005 was used to develop the best algorithms for the forward prediction of Microcystis biomass. The model was trained on 12 years' data from each dam, providing a set of 36 years' combined data for the 3 dams, while setting aside 2 years of data from each dam on which to test the developed algorithm. Thus 6 years of data were available for testing the algorithm (Fig. 7).

Sensitivity analysis indicates that initial biomass (estimated from chlorophyll $a$ ) and surface temperature, are the most important environmental variables for the 7-day forward prediction of Microcystis biomass in hypertrophic systems.

Under low phytoplankton-growth conditions the increases in initial biomass and surface temperature are the most important environmental variables contributing to the increase in Microcystis biomass. Under bloom-forming conditions, the increased changes in Microcystis biomass are primarily explained by the total phosphorus concentrations within the system (See Fig. 8).

\section{Epilimnion disturbance through laminar flow}

Epilimnion mixing is one of the most appropriate methods of combating cyanobacterial blooms (Hart and Hart, 2006). For this reason, the City of Tshwane, through their Rietvlei Water Treatment Works and in collaboration with the Department of Water Affairs, purchased 6 SolarBee ${ }^{\circledR}$ (patented solar-powered water circulator) pumping units and installed them in Rietvlei Dam in July 2008. The instruments were placed primarily near the intake water inflow into Rietvlei Dam. These instruments 


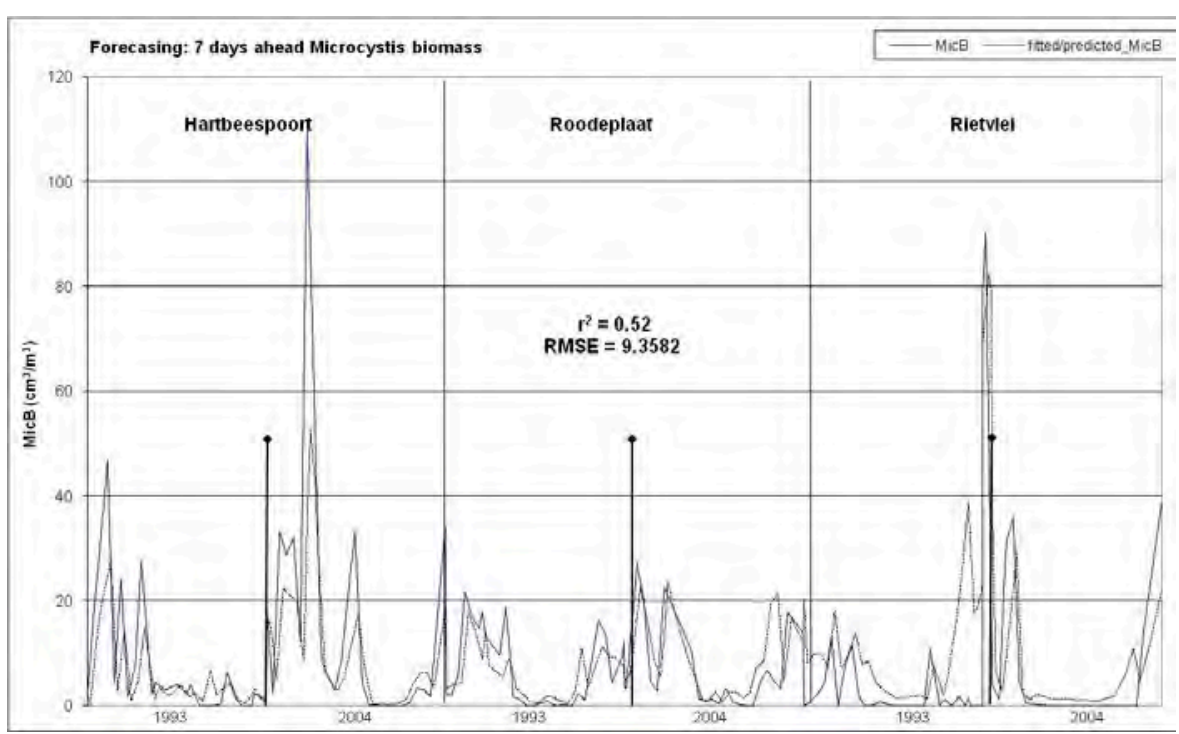

Figure 7

Test results of the 7-day forward forecasting of Microcystis biomass in the Hartbeespoort, Rietvlei and Roodeplaat Reservoirs using the best developed rule set as shown in Fig. 8 (Van Ginkel et al., 2009)

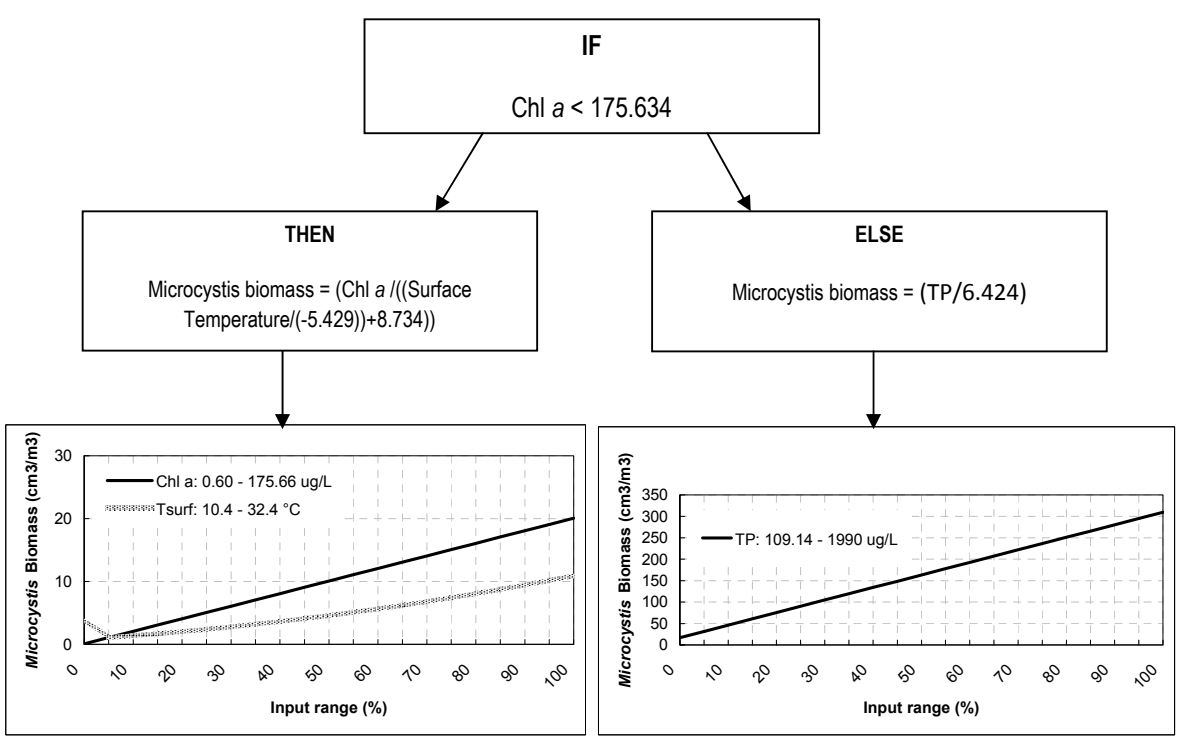

Figure 8

Sensitivity analysis of the input data for the THEN-branch (left) and the ELSE-branch (right) of the best developed rule set for 7-day forward forecasting of Microcystis biomass using the median concentrations of the most important environmental variables to determine the sensitivity of the Microcystis biomass prediction to important variables (Van Ginkel et al., 2009)

cause laminar flow that disturbs the water column to such an extent that conditions become unfavourable for cyanobacterial growth. Another 10 SolarBees were purchased in 2009 and placed in the dam, which is now covered extensively by these 16 devices.

The SolarBees in Rietvlei Dam are set up with the intake hoses at a depth of $4 \mathrm{~m}$ in order to cause laminar flow and disturb the stability of the epilimnion. The systems therefore do not cause complete mixing throughout the thermocline. The City of Tshwane is monitoring Rietvlei Dam regularly to assess the effectiveness of the SolarBee ${ }^{\circledR}$ instruments under South African conditions. The WRC is funding a follow-up project to the forward prediction model development, which is testing the model at the Rietvlei Dam Water Treatment Works. According to Coetzee (2011) the phytoplankton community has since installation of the SolarBee ${ }^{\circledR}$ instruments shifted away from the regular annual cyanobacterial blooms.

\section{Adaptive eutrophication management}

Various initiatives are under way for managing eutrophication in South Africa. The nation's research advisors will need to develop strategies to implement the most effective methods. One way to formalise the process is through adaptive eutrophication management (Fig. 10). Herewith the 6 steps that should be followed for successful adaptive eutrophication management:

\section{- Step 1: Monitoring}

Monitoring is the first step in combating the problem. If monitoring does not happen, the extent of the problem, or sites in need of management, will not be known. Monitoring the extent of eutrophication in the country should lead to directed research to discover or investigate the most appropriate methods to implement at each impacted site.

- Step 2: Directed research Directed research determines the most effective management options for each specific site. This may be done by investigating all potential management options on small or large scale, leading to a better understanding of the problem. Directed research encourages the development of new monitoring methodology, management, and predictive capabilities, nutrient-limiting approaches and in-lake management options. Preferably, research or investigation of each management option should take place at different localities, to enable prioritisation according to efficiency and financial implications. In this way, management options can be considered in isolation and decisions can be based on scientifically sound research. This process will provide managers with several options to select from, when developing the management plans for a specific site.

\section{- Step 3: Develop plans}

Next, the selected eutrophication-management plans need to be developed with a view to implementation. An adequate budget is essential for this purpose. 


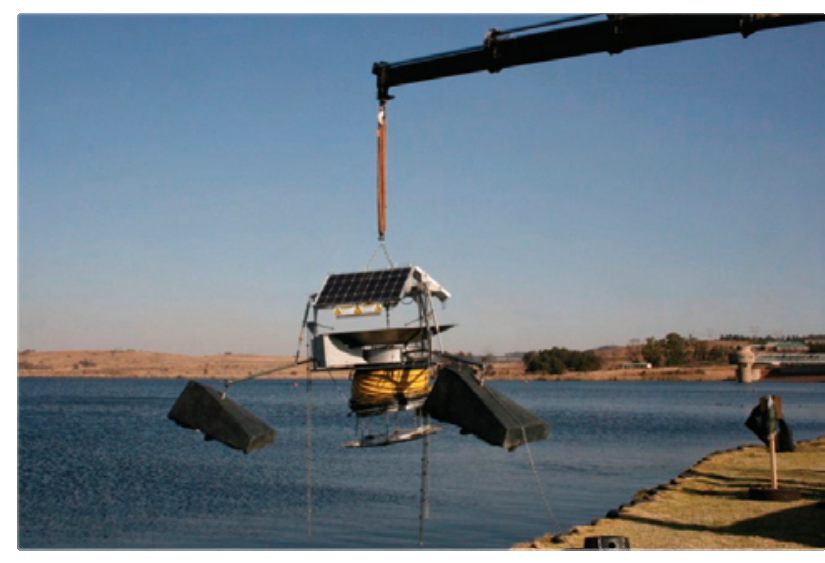

Figure 9

Deployment of a SolarBee $₫$ laminar flow pumping unit in Rietvlei Dam during 2008

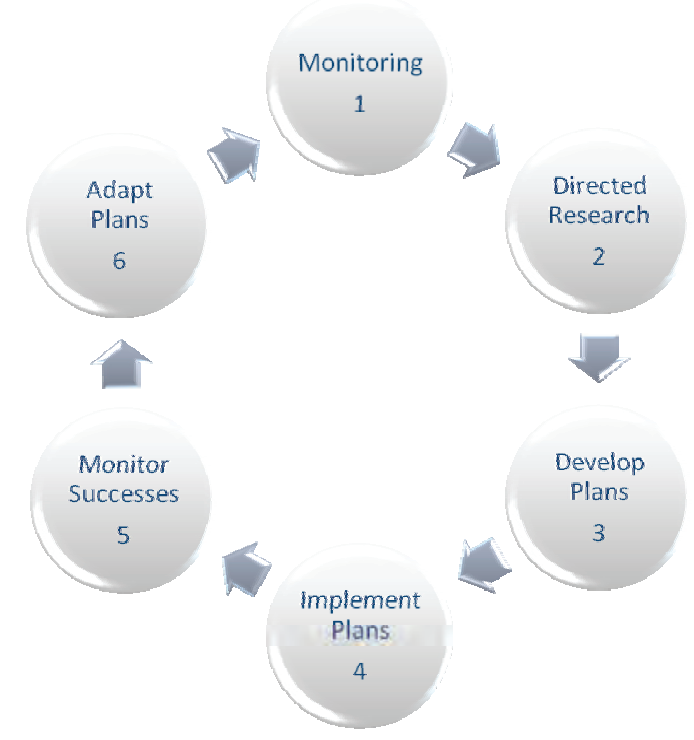

Figure 10

The 6 steps in the adaptive eutrophication management system

\section{- Step 4: Implement plans}

Next, the eutrophication-management plans need to be implemented. Budgeting for sufficient funds is the sole responsibility of the national, regional and local institutions.

\section{- Step 5: Monitor successes}

The functioning of implemented plans needs to be monitored and reported on in order to determine their effectiveness. When successes and failures are monitored and documented well, decisions to adapt management plans should fall in place.

\section{- Step 6: Adapt plans}

The management plans need to be adapted, if necessary. Adaptation aligned to the outcome of implementation monitoring should ensure that the necessary funding is available for implementing the adapted implementation plans.

The responsibility to manage eutrophication in South Africa lies with the national, regional and local management institutions. In addition to the measures outlined in Steps 2, 3, 5 and 6 , research institutions at national, regional and local levels should apply their knowledge in order to assist and improve eutrophication management in South Africa.

By following these 6 steps, South African water-resource managers can select the appropriate eutrophication-management strategy for each impacted site. This pre-empts crisis control. Sustainable management plans can be implemented to ensure safe water and accessible recreational sites to all end users.

Many control methods have been suggested and tested internationally:

Nutrient minimisation

- Nutrient inactivation

- Flow augmentation or flushing

- Hypolimnetic aeration

- Destratification

- Selective removal of hypolimnetic water

- Laminar epilimnion disturbance

- Water-level drawdown

- Covering bottom sediment

- Dredging

- Harvesting

- Biomanipulation

- Chemical control

Research on the effectiveness and applicability of these different methods in South Africa is critically important. The results will assist in selecting eutrophication-control measures suitable for South African climatic and economic conditions, in order to reach the ultimate goal of combating eutrophication sustainably in South African inland waters.

\section{Conclusions}

Eutrophication is a serious problem in a number of catchment areas in South Africa which appears to have escalated over time. The root of the problem is nutrient enrichment in freshwater resources and therefore the most important management approach involves minimising the influx of nutrients into freshwater systems. However, this approach is being supplemented with several other methods that are currently being evaluated or have been assessed in the recent past. The contributions of the Water Research Commission, the Department of Water Affairs, the CSIR, and their co-workers have been fundamental in creating the substantial knowledge base that already exists. Integrated water resource management for eutrophication should include:

- Continued monitoring programmes

- Continued initiatives to reduce the release of phosphorus into water resources; e.g. by introducing the use of low-P detergents

- The development of a knowledge base encompassing all efficient and viable eutrophication-management options for South African climatic conditions and social requirements

- In-lake management options for sites that are already hypertrophic

- Consideration of the further implementation of effective eutrophication-management methods to be used at further impacted sites

- Ensuring adequate funding and efficient expenditure to combat the problem of nutrient enrichment of freshwater resources in a sustainable manner.

\section{References}

ANONYMOUS (1988a) Phosphate standard now strictly enforced. SA Waterbulletin 14 (5) 22. 
ANONYMOUS (1988b) Special phosphate standard for sensitive catchments. Water Sewage Effl. 8 (4) 10-11.

BOTES E, GROBBELAAR JU, OBERHOLSTER AM, OBERHOLSTER PJ and VAN DEN HEEVER JA (2004) Toxin production by cyanobacteria. WRC Report 1029/1/04. Water Research Commission, Pretoria, South Africa.

BYRNE M, HILL M, ROBERTSON M, KING A, JADHAV A, KATEMBO N, WILSON J, BRUDVIG R and FISHER J (2010) Integrated Management of Water Hyacinth in South Africa: Development of an Integrated Management Plan for Water Hyacinth Control, Combining Biological Control, Herbicidal Control and Control, Tailored to the Climatic Regions of South Africa. WRC Report No. TT 454/10. Water Research Commission, Pretoria, South Africa. 285 pp.

CILLIERS CJ, ZELLER D and STRYDOM G (2003) Short and longterm control of water lettuce (Pistia stratioted) on seasonal water bodies and on a river system in the Kruger National Park, South Africa. Hydrobiol. 340 (1-3)173-179.

CILLIERS CJ (1991) Biological control of water hyacinth in South Africa. Agric. Ecosyst. Environ. 37 1-3. (Special issue: Biological Control of Weeds in South Africa). Elsevier.

COETZEE JA, HILL MP, BYRNE MJ and BOWNES A (2011a) A review of the biological control programmes on Eichhornia crassipes (C.Mart.) Solms (Pontederiaceae), Salvinia molesta (D.S. Mitch.), (Salviniaceae), Pistia stratiotes L. (Araceae), Myriophyllum aquaticum (Vell) Verdc. (Haloragaceae) and Azolla filiculoides Lam. (Azollaceae) in South Africa. In: Moran VC, Hofmann JH and Hill MP (eds.) Biological Control of Invasive Alien Plants in South Africa (1999-2010). Afr. Entomol. 19 (2) Special Issue. 451-468.

COETZEE JA, BOWNES A and MARTIN GD (2011b) Prospects for the biological control of submerged macrophytes in South Africa. In: Moran VC, Hofmann JH and Hill MP (eds.) Biological Control of Invasive Alien Plants in South Africa (1999-2010). Afr. Entomol. 19 (2) Special Issue. 469-487.

COETZEE L-A (2011) Personal communication, 19 July 2011. Manager, City of Tshwane Rietvlei Water Treatment Works.

DEPARTMENT OF WATER AFFAIRS (DWA) (1988) Important announcement on implementation of the special phosphate standard in sensitive catchments. IMIESA (Johannesburg) 13 (9) 35.

DWAF (DEPARTMENT OF WATER AFFAIRS AND FORESTRY, SOUTH AFRICA) (DWAF) (2002) National Eutrophication Monitoring Programme. Implementation Manual. Compiled by K Murray, M du Preez and CE van Ginkel. Department of Water Affairs and Forestry, Pretoria. South Africa.

DOWNING TG and VAN GINKEL CE (2004) Cyanobacterial monitoring 1990-2000: Evaluation of SA data. WRC Report No. 1288/1/04. Water Research Commission, Pretoria, South Africa.

FROST \& SULLIVAN (2010) Eutrophication Research Impact Assessment. WRC Report No. TT 461/10. Water Research Commission, Pretoria, South Africa.

GROBLER DC and SILBERBAUER MJ (1984) Impact of Eutrophication Control Measures on the Trophic Status of South African Impoundments. WRC Report No.130/1/84. Water Research Commission, Pretoria, South Africa.

HARDING WR (2006) A Research Strategy for the Detection and Management of Algal Toxins in Water Sources. WRC Report No. TT 277/06. Water Research Commission, Pretoria, South Africa.

HARDING WR (2008) The Determination of Annual Phosphorus Loading Limits for South African Dams. WRC Report No. 1687/1/08. Water Research Commission, Pretoria, South Africa.

HARDING WR and PAXTON BR (2001) Cyanobacteria in South Africa: A Review. WRC Report No. TT 153/01. Water Research Commission, Pretoria, South Africa. ISBN: 1-86845-774-5.

HART R and HART RC (2006) Reservoirs and their Management: A Review of the Literature since 1990. WRC Report No. KV/173/06. Water Research Commission, Pretoria, South Africa. ISBN: 1-77005-418-9.

HOHLS BC, QUIBELL G, DU PLESSIS BJ and BELCHER T (1998) Assessment of the Implementation of the Phosphate Standard at the Baviaanspoort and the Zeekoegat Water Care Works. Report No. N/A230/01/DEQ/0797. Institute for Water Quality Studies
(Resource Quality Services), Department of Water Affairs and Forestry, Pretoria, South Africa.

JOHNSTON BR and JACOBY JM (2003) Cyanobacterial toxicity and migration in a mesotrophic lake in Western Washington, USA. Hydrobiol. 495 79-91.

JONES R and LEE GF (1986) Eutrophication modelling for water quality management: An update of the Vollenweider-OECD Model. Water Res. 16 503-515.

LINDHOLM T, VESTERKVIST P, SPOOF L, LUNDBERGNIINISTÖ C and MERILUOTO J (2003) Microcystin occurrence in lakes in Åland, SW Finland. Hydrobiol. 505 129-138.

MODJADJE VEGETATION (2008) Compliance Audit on the Management of Aquatic Weeds in South African Waterways. Report No. DWAF/RSA/01-0707. Department of Water Affairs and Forestry, Pretoria, Republic of South Africa.

OBERHOLSTER PJ, MYBURGH JG, GOVENDER D, BENGIS R and BOTHA A-M (2009) Identification of toxigenic Microcystis strains after incidents of wild animal mortalities in the Kruger National Park, South Africa. Ecotoxicol. Environ. Saf. 72 (4) 1177-1182.

PILLAY M and BUCKLEY CA (2001) Detergent Phosphorus in South Africa: Impact on Eutrophication with Specific Reference to Mgeni Catchment. WRC Report No. 465/1/01. Water Research Commission, Pretoria, South Africa.

POURIA S, DE ANDRADE A, BARBOSA J, CAVALCANTI RL, BARRETO VT and WARD CJ (1998) Fatal microcystin intoxication in haemodialysis unit in Caruaru, Brazil. Lancet 352 21-26.

QUAYLE LM (2011) Personal communication, 31 August 2011. Researcher, Institute of Natural Resources (INR), PO Box 100396, Scottsville 3209, KwaZulu-Natal.

QUAYLE LM, DICKENS CWS, GRAHAM M, SIMPSON D, GOLIGER A, DICKENS JK, FREESE S and BLIGNAUT J (2010) Investigation of the Positive And Negative Consequences Associated with the Introduction of Zero-Phosphate Detergents into South Africa. WRC Report No. TT 446/10. Water Research Commission, Pretoria, South Africa. 159 pp.

ROSSOUW JN (1990) Final report on the Development of Management-Orientated Models for Eutrophication Control. WRC Report No. 174/1/90. Water Research Commission, Pretoria, South Africa.

ROSSOUW JN, HARDING W R and FATOKI OS (2008) A Guide to Catchment-Scale Eutrophication Assessments for Rivers, Reservoirs and Lacustrine Wetlands. WRC Report No. TT 352/08. Water Research Commission, Pretoria, South Africa.

SWANEPOEL A, DU PREEZ H, SCHOEMAN C, JANSE VAN VUUREN S and SUNDRAM A (2008) Condensed Laboratory Methods for Monitoring Phytoplankton, Including Cyanobacteria, in South African Freshwaters. WRC Report No. TT 323/08. Water Research Commission, Pretoria, South Africa.

TAYLOR R, BEST HJ and WIECHERS HNS (1984) The effluent phosphate standard in perspective: Part 1: Impact, control and management of eutrophication. IMIESA (October 1984) 43-56.

THORNTON JA and HARDING WR (2005) Eutrophication in African lakes with particular reference to phosphorus modelling. In: Crisman TL, Chapman LJ, Chapman CA and Kaufman LS (eds.) Conservation, Ecology and Management of African Freshwaters. University Press of Florida, Gainesville, USA.

TOERIEN DF (1977) A Review of Eutrophication and Guidelines for its Control in South Africa. CSIR Special Report WAT 48. CSIR, Pretoria, South Africa.

VAN DER MERWE W (1989) Application of a phosphate standard in the RSA. In: Proc. Phosphorus Symp. Pretoria, South Africa. 209-211.

VAN GINKEL CE (2004) A National Survey of the Incidence of Cyanobacterial Blooms and Toxin Production in Major Impoundments. Resource Quality Services Report No. N/0000/00/ DEQ/0503, Department of Water Affairs and Forestry, Pretoria, South Africa. 44 pp.

VAN GINKEL CE (2011) Unpublished Hartbeespoort Dam zooplankton data.

VAN GINKEL CE and CONRADIE B (2001) Potentially Toxic Algal Incident in the Orange River, Northern Cape, 2000. Internal Report No. N/D801/12/DEQ/0800. Resource Quality Services (Institute 
for Water Quality Studies), Department of Water Affairs and Forestry, Pretoria, South Africa.

VAN GINKEL CE, HOHLS BC, BELCHER A, VERMAAK E and GERBER A (2001) Assessment of the Trophic Status Project. Internal Report No. N/000/00/DEQ/1799. Resource Quality Services (Institute for Water Quality Studies). Department of Water Affairs and Forestry, Pretoria. South Africa.

VAN GINKEL CE, DU PLESSIS S and BEZUIDENHOUT JJ (2009) Investigating the Applicability of Ecological Informatics Modelling Techniques for Predicting Harmful Algal Blooms in Hypertrophic Reservoirs of South Africa. WRC Report No. TT 451-09. Water Research Commission, Pretoria, South Africa.

VAN GINKEL CE, O'KEEFFE JH, HUGHES DA, HERALD JR and ASHTON PJ (1996) A Situation Analysis of Water Quality in the Catchment of the Buffalo River, Eastern Cape, with Special Emphasis on the Impacts of Low Cost, High-Density Urban Development on Water Quality. Volume 2 (appendices). WRC Report No. 405/2/96. Water Research Commission, Pretoria, South Africa.

VAN GINKEL CE, SILBERBAUER MJ, DU PLESSIS S and CIC (2006) Monitoring microcystin toxin and chlorophyll in five South
African impoundments. Verh. Int. Ver. Limnol. 29 1611-1616. WALMSLEY RD (2000) Perspectives on Eutrophication of surface waters: Policy/research needs in South Africa. WRC Research Report No. KV 129/00. Water Research Commission, Pretoria, South Africa.

WALMSLEY RD and BUTTY M (1980) Guidelines for the Control of Eutrophication in South Africa. WRC Special Report. Water Research Commission, Pretoria, South Africa.

WATER (1988) Phosphate standard implemented. Water, September 1989, Pretoria.

WNOROWSKI AU (1992) Taste and Odour Forming Microorganisms in South African Surface Waters. WRC Report No. 320/1/93. Water Research Commission, Pretoria. South Africa. ISBN 1-87485-895-0.

WORLD HEALTH ORGANIZATION (WHO) (1999) Toxic Cyanobacteria in Water. A Guide to Their Public Health Consequences, Monitoring and Management. Edited by Chorus I and Bartram J. E\&FN Spon. London. ISBN: 0-41923-930-8.

ZOHARY T, JARVIS AC, CHUTTER FM, ASHTON PJ and ROBARTS RD (1988) The Hartbeespoort Dam Ecosystem Programme. CSIR, WRC Pretoria, South Africa. 
http://dx.doi.org/10.4314/wsa.v37i5.6 Available on website http://www.wrc.org.za

ISSN 0378-4738 (Print) = Water SA Vol. 37 No. 5 WRC 40-Year Celebration Special Edition 2011 ISSN 1816-7950 (On-line) = Water SA Vol. 37 No. 5 WRC 40-Year Celebration Special Edition 2011 